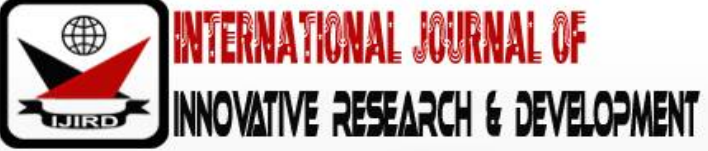

ISSN 2278 - 0211 (Online)

\section{Modelling and Simulation of Biofilter System for Abattoir Wastewater Treatment}

\author{
Esther Adedayo Olatundun. \\ Principal Engineer, Department of Research and Development \\ Prototype Engineering Development Institute, (National Agency for Science and Engineering \\ Infrastructure), Ilesa, Osun State, 233036, Nigeria \\ Kolawole Rasheed Onifade \\ Professor, Department of Chemical Engineering, Federal University of Technology, Nigeria
}

\begin{abstract}
:
The treatment of wastewater from abattoir using conventional wastewater treatment such as sedimentation and landfilling is associated with difficulty of complete organic matter removal. In the treatment of wastewater from abattoir, biofilter system has the capacity to treat very large volume of wastewater as well as achieve complete organic matter removal without polluting the environment. In this study, biofilter system for abattoir wastewater treatment process was modelled and simulated for complete organic matter removal. Biofilter system which included three aerators, ultrafilter, clarifier and storage tank was designed and simulated on a process simulator (Super Pro designer 4.53) and also, the mathematical model of the biofilter system was developed from the law of conservation of matter. Four design configurations that consisted of feed inlet stream of glucose, biomass, water and benzene having four different compositions (100\%, 75\%, 50\% and $25 \%)$ were considered in the modelling and simulation. Disturbances in benzene concentrations were used to test the effectiveness of the proposed biofilter design configuration. The results of the mathematical models were compared with that of the process simulator using t-test at $\mathrm{p}<0.05$. The simulation results showed that glucose, benzene and biomass reduced in concentration from 4.95 to $0.00 \mathrm{~g} / \mathrm{l}, 0.63$ to $0.00 \mathrm{~g} / \mathrm{l}$ and 0.10 to $0.004 \mathrm{~g} / \mathrm{l}$, respectively. While the concentration of water increased from 989.70 to $994.45 \mathrm{~g} / \mathrm{l}$. The model results also revealed a reduction in the concentration of benzene, glucose, biomass and water from 0.63 to $0.37 \mathrm{~g} / \mathrm{l}, 4.95$ to $2.92 \mathrm{~g} / \mathrm{l}, 0.10$ to $0.06 \mathrm{~g} / \mathrm{land} 989.70$ to $583.65 \mathrm{~g} / \mathrm{l}$, respectively.The biofilter system removed up to $99.90 \%$ of both Biochemical Oxygen Demand (BOD) and Chemical Oxygen Demand (COD),95\% of Total Suspended Solid (TSS), and 95.73\% of both Total Kjehdahl Nitrogen (TKN) and Total Phosphorus (TP), respectively. There were significant differences in the results of the mathematical modelling and process simulator at $p<0.05$. Super Pro designer 4.53 and mathematical modelling have been shown to be suitable tools for the design of a biofilter system for abattoir wastewater treatment.
\end{abstract}

Keywords: Wastewater treatment, abattoir, biofilter system, superPro designer, process simulator

\section{Introduction}

Abattoir operations produce a characteristic highly organic waste with relatively high levels of suspended solid, liquid and fat. The solid waste includes condemned meat, undigested ingesta, bones, horns, hairs and aborted foetuses. The liquid waste is usually composed of dissolved solids, blood, gut contents, urine and water [1]. While the slaughtering of animals results in meat supply and useful by-products like leather and skin, livestock waste spills can introduce enteric pathogens and excess nutrients into surface waters and can also contaminate ground water [2]. This wastewater is frequently contaminated by significant levels of antibiotics and growth hormones from the animals and by a variety of pesticides used to control external parasites. According to Masse and Masse (2000), abattoir (slaughterhouse) wastewater is very harmful to the environment [3]. Effluent discharge from slaughterhouses has caused the deoxygenation of rivers [4] and the contamination of groundwater [5]. The pollution potential of meat-processing and slaughterhouse plants has been estimated at over 1 million population equivalents in the Netherlands and 3 million in France [6]. Blood, one of the major dissolved pollutants in slaughterhouse wastewater, has a Chemical Oxygen Demand (COD) of $375000 \mathrm{mg} / \mathrm{L}$ [7]. Slaughterhouse wastewater also contains high concentrations of suspended solids (SS), including of grease, feathers, flesh, manure, grit, and undigested feed [8]. These insoluble and slowly biodegradable SS represented $50 \%$ of the pollution charge in screened $(1 \mathrm{~mm})$ slaughterhouse wastewater, while another $25 \%$ originated from colloidal solids [9]. Slaughterhouse wastewater quality depends on a number of factors, namely:

a) Blood capture: the efficiency in blood retention during animal bleeding is considered to be the most important measure for reducing Biological Oxygen Demand (BOD) [7]; b) Water usage: water economy usually translates into increased pollutant concentration, although total BOD mass will remain constant; c) Type of animal slaughtered: BOD is higher in wastewater from beef than hog slaughterhouses [7]; d) Amount of rendering or meat processing activities: 
plants that only slaughter animals produce a stronger wastewater than those also involve in rendering or meat processing activities [10]. In waste water, organic matters are usually quantified by biodegradable oxygen demand (BOD), chemical oxygen demand (COD), biodegradable dissolved organic carbon (BDOC), and total organic carbon (TOC) measurement. The presence of organic matters in water, even in a low concentration can directly affect water quality. Organic matters in water are the source of nutrient for aquatic microorganisms including opportunistic pathogens regrowth in the distribution systems. Organics also react with disinfectants such as chlorine and ozone to form potential carcinogenic and harmful disinfection by-products. In addition, organic matter can impair the colour, odour and taste of water [11].Even though organic matter can be removed in a large portion by conventional waste water treatment processes like sedimentation and land treatment, it is difficult to be completely removed. Therefore, organic matter removal is important in advanced water treatment to meet water quality requirements. The use of a biofilter is one of the treatment processes that can effectively remove organic matters that cannot be removed by conventional sewage treatments.

\subsection{Biofilter System}

Biofilters perform the removal and oxidation of compounds from contaminated water using microorganisms. The technique of biofiltration has been successfully used in water and wastewater treatment for over a century [12]. Biofiltration has shown to be a promising technique for handling malodours arising from process industries including abattoirs [13]. Many studies have shown that biofilter can remove most organic matter from water and wastewater with less operational and maintenance requirements [11]. The treatment function of the biological filter is based on the activities of microorganism communities that are attached on to filter media. Organic substances in the influent are adsorbed on the biomass and then biodegraded by the microbes. Aerobic conditions are maintained by splashing, diffusion, and either by forced air flowing through the bed or natural convection of air if the filter medium is porous. The process mechanism, or how the removal of waste from the water happens, involves both absorption and adsorption of organic compounds within the sewage or other wastewater by the layer of microbial slime. Aerobic bacteria are very efficient in breaking down waste products. The result of this is; aerobic treatment usually yields better effluent quality than that obtained in anaerobic processes. The aerobic pathway also releases a substantial amount of energy. A portion is used by the microorganisms for synthesis and growth of new microorganisms.

Diffusion of the wastewater over the media furnishes dissolved air, the oxygen which the slime layer requires for the biochemical oxidation of the organic compounds and releases carbon dioxide gas, water and other oxidized end products. As the slime layer thickens, it becomes more difficult for air to penetrate the layer and an inner anaerobic layer is probably formed. This slime layer continues to build until it eventually sloughs off, breaking off longer growth into the treated effluent as a sludge that requires subsequent removal and disposal. Typically, a trickling filter is followed by a clarifier or sedimentation tank for the separation and removal of the sloughing. Other filters utilizing higher-density media such as sand, foam and peat moss do not produce a sludge that must be removed, but require forced air blowers and backwashing or an enclosed anaerobic environment. In the view of Wik (2003), a biofilter is an attached growth bioreactor that uses a plastic or mineral inert media as biofilm substratum [14]. Water is distributed over a tower with packed media and as the water trickles down, the microorganisms in the biofilm degrade organic matter, nitrify, denitrify etc. depending on the operating conditions.

A filter removes a small percentage of the suspended organic matter, while the majority of the organic matter undergoes biological oxidation and nitrification takes place in the filter. With this aerobic oxidation and nitrification, the organic solids are converted into coagulated suspended mass, which is heavier and bulkier, and can settle to the bottom of a tank. The effluent of the filter is therefore passed through a sedimentation tank.

\subsection{Biological Treatment Options}

There are three basic categories of biological treatment: aerobic, anaerobic and anoxic. Aerobic biological treatment, which may follow some form of pre-treatment such as oil removal, involves contacting wastewater with microbes and oxygen in a reactor to optimize the growth and efficiency of the biomass. The microorganisms act to catalyze the oxidation of biodegradable organics and other contaminants such as ammonia, generating innocuous byproducts such as carbon dioxide, water, and excess biomass (sludge). Microorganisms require free dissolved oxygen to reduce the biomass in the wastewater. The biological sludge must be treated before disposal [10]. Aerobic treatments are very effective at reducing odours and pathogens [15].Anaerobic (without oxygen) and anoxic (oxygen deficient) treatments are similar to aerobic treatment but use microorganisms that do not require addition of oxygen. These microorganisms use compounds other than oxygen to catalyze the oxidation of biodegradable organics and other contaminants, resulting in innocuous by-products. Aerobic digestion of waste is the natural biological degradation and purification process in which bacteria that thrive in oxygen-rich environments break down and digest the waste. During oxidation process, pollutants are broken down into carbon dioxide $\left(\mathrm{CO}_{2}\right)$, water $\left(\mathrm{H}_{2} \mathrm{O}\right)$ and biomass (microorganisms) and operating the oxygen supply with aerators, the process can be significantly accelerated.

\subsection{Applicability of Biofilters}

According to United States Environmental Protection Agency (USEPA) (2000), biofilters enable organic material in the wastewater to be adsorbed by a population of microorganisms (aerobic, anaerobic, and facultative bacteria; fungi; algae; and protozoa) attached to the medium as a biological film or slime layer (approximately 0.1 to $0.2 \mathrm{~mm}$ thick) [16].The biomass can include bacteria (Bacillus subtilis, Bacillus licheniformis), yeast (Candida tropicalis), fungus 
(Aspergillusniger, Penicilliumchryosogenum, Rhizopusarrhizus), algae (Sargassumnatans, Ascophyllumrodosum, Fucusvesiculosus) and plant material (peat moss, wood chips and pine cones).

As the wastewater flows over the medium, microorganisms already in the water gradually attach themselves to the rock, slag, or plastic surface and form a film. The organic material is then degraded by the aerobic microorganisms in the outer part of the slime layer. As the layer thickens through microbial growth, oxygen cannot penetrate the medium face, and anaerobic organisms develop. As the biological film continues to grow, the microorganisms near the surface lose their ability to cling to the medium, and a portion of the slime layer falls off the filter. This process is known as sloughing. The sloughed solids are picked up by the under-drain system and transported to a clarifier for removal from the wastewater.

\subsection{Modelling and Simulation of Biofilter}

A model is a simplified representation of a system at some particular point in time or space intended to promote understanding of the real system. It is a simplified representation of the actual system intended to promote understanding. Simulation is the manipulation of a model in such a way that it operates on time or space to compress it, thus enabling one to perceive the interactions that would not otherwise be apparent because of their separation in time or space. Modelling and simulation of biofilter is a system for developing a level of understanding of the interaction of the parts of the biofilter system, and of the system as a whole [17].

Biofilter modelling started in the early 1980s and was based on earlier work on submerged biofilm models. The models assumed basic mass balance principles, simple reaction kinetics, and a plug flow stream. More recently, fundamentally different but potentially promising type of models, use quantitative structure activity relationships and seek to predict the performance of biofilters from data describing the removal of a few known pollutants. The difficulty in modelling a biofilter lies in the complexity of the fundamental processes.

Biofiltration involves many physical, chemical, and microbiological phenomena. In order to simulate biofilter effectiveness with varying operating conditions, a model must include these various phenomena. Further, a number of unknowns or difficulties exist in the definition of equations for a biofilter model [18]. There are only a few models reported in the literature that can predict the performance of a biofilter. Most of these models are based on the assumption of stationary and uniform flow.

\subsection{Unit Operations of Biofilter}

The operations in the biofilter can be summarized as aerobic bio-oxidation, ultra-filtration and clarification.

\subsection{Aerobic bio-oxidation}

This is the breakdown of organic contaminants by microorganisms when oxygen is present. More specifically, it refers to occurring of living only in the presence of oxygen; therefore, the chemistry of the system, environment, or organism is characterized by oxidative conditions. Many organic contaminants are rapidly degraded under aerobic conditions by aerobic bacteria called aerobes. Aerobic bacteria (aerobe) have an oxygen-based metabolism. Aerobes, in a process known as cellular respiration, use oxygen to oxidize substrates (for example sugars and fats) in order to obtain energy.

\subsection{Ultrafiltration}

Ultrafiltration is a variety of membrane filtration in which hydrostatic pressure forces a liquid against a semi permeable membrane. Suspended solids and solutes of high molecular weight are retained, while water and low molecular weight solutes pass through the membrane [19].

\subsection{Clarification/ Sedimentation}

It is a physical water treatment process used to settle out suspended solids in water under the influence of gravity. Sedimentation in potable water treatment generally follows a step of chemical coagulation and flocculation, which allows grouping particles together into flocs of a bigger size. This increases the settling speed of suspended solids and allows settling colloids. Sedimentation is often used as a primary stage in modern waste water treatment plant, reducing the content of suspended solids as well as the pollutant embedded in the suspended solids [20].

\subsection{Characterization of Abattoir Wastewater Streams}

The chemical and biological components of wastewater streams themselves are also of great interest to the meat processing industry, due to their relative high strength in wastewater effluent streams. The most notable environmental impact directly attributable to the industry involves the massive quantities of water used in abattoirs for cleaning, transport, and processing of meat and meat products. Abattoir wastewater has a complex composition and is very harmful to the environment [21]. It is stronger in terms of pollutant (microbial) load compared to domestic wastewater; the reason for using three bioreactors in series. Using a stirred reactor assists micro-organisms to maintain close contact with the waste to improve efficiency of hydrolytic activity. The decomposition of organic waste is performed by aerobic bacteria, yeasts and fungi.

\subsection{Classification of Meat Processing Wastewater Streams}

Wastewater streams in the meat processing industry are classified as low- or high-strength due to their concentrations of the following biological and chemical contaminants: 
- Biochemical Oxygen Demand (BOD), commonly referred to as $\mathrm{BOD}_{5}$, which stands for the amount of oxygen demand over five days at a constant temperature,

- Chemical Oxygen Demand (COD),

- Total Suspended Solids (TSS),

- Nitrogen,

- Phosphorus, and

- Total faecal coli form bacteria, commonly given in colony-forming units (CFU) per volume of wastewater.

\subsection{Other Components of Abattoir Wastewater}

\begin{tabular}{|c|c|c|}
\hline Component & Flow rate (kg/ h) & Concentration (g/ l) \\
\hline Water & $156,600.00$ & 995.99 \\
\hline Glucose & 783.00 & 4.98 \\
\hline Benzene & 100.00 & 0.63 \\
\hline Biomass & 15.66 & 0.10 \\
\hline
\end{tabular}

Table 1: Components, Flow Rates and Concentrations of Abattoir Wastewater Source: Superpro Designer (1991)

SuperPro Designer is a tool for engineers and scientists in process development, process engineering, and manufacturing. It is also claimed to be a tool for professionals dealing with environmental issues (e.g., wastewater treatment, air pollution control, waste minimisation, pollution prevention).

\section{Research Methodology}

Design of a biofilter which involved three aerators (equivalent to bioreactors in series), ultrafilter, clarifier and storage tank was carried out using commercial software - SuperPro designer 4.53. The model was derived from the law of conservation of matter so as to develop model equations in order to get model results. Four design configurations that involved feed inlet stream of glucose, biomass, benzene and water with four different loads of benzene compositions were considered.

The first configuration was at $100 \%$ of benzene concentration with other components, the second at $75 \%$, the third at $50 \%$ while the fourth was at $25 \%$. The simulation of these configurations with their individual specifications was carried out in the biofilter system. Disturbances in benzene concentrations were used to test the effectiveness of the proposed biofilter design configuration. Analytical modelling by law of conservation of matter to develop the governing equations and numerical simulation were carried out with the aid of SuperPro Designer. The results of the mathematical models were compared with that of the process simulator using t-test at $\mathrm{p}<0.05$.

Procedural steps to modelling are;

Starting with the design equation i.e. $\mathrm{C}_{\mathrm{A} 1}=\frac{\mathrm{C}_{\mathrm{AO}}}{(1+\tau \mathrm{k})}$

Substituting all the parameters into the equation, in which $\mathrm{C}_{\mathrm{A} 1}$ is the unknown to be determined

$\mathrm{C}_{\mathrm{AO}}$ is the initial concentration entering into the first tank in $\mathrm{g} / \mathrm{L}, \tau$ is the residence time in $\mathrm{hr}$ (total residence time is $6 \mathrm{hrs}$, since $\tau$ total $=\mathrm{n} \tau, \tau=2 \mathrm{hrs}$ for the 3 bioreactors) and $\mathrm{K}$ is the reaction rate constant in hr-1 which is calculated as; $\mathrm{K}=\mathrm{K}_{\text {max }_{0}} \theta^{\mathrm{T}-\mathrm{T}_{0}}$

Where $\mathrm{K}=0.08 \times 1.04^{25-20}$

$\mathrm{K}=0.08 \times 1.04^{5}=0.08 \times 1.2167=9.733 \times 10^{-2}$

$\mathrm{K}=0.0973 \mathrm{hr}^{-1}$

Determining $\mathrm{C}_{\mathrm{A} 1}$ which is the concentration of components in the second tank. This same procedure will be carried out to calculate $\mathrm{C}_{\mathrm{A} 2}$ and also for $\mathrm{C}_{\mathrm{A} 3}$

The only challenging aspect of this model is that generation and degradation of components were not considered due to their complexity. Results from mathematical model were now compared with the results from simulation using Super Pro designer 4.53 in terms of their percentage yield and purity. The key problem associated with conventional treatment process of wastewater from abattoir is that the organic matters are difficult to remove, hence the need for a more efficient treatment process that can reduce microbial loads in wastewater.

\subsection{Growth Kinetics}

The growth kinetics is assumed to follow Monod equation which is the most widely used kinetic equation to describe substrate, assuming no oxygen limitations. Growth is expressed as:

$\mathrm{r}_{\mathrm{XB}}=-\mathrm{Yr}_{\mathrm{S}}$

$\mathrm{r}_{\mathrm{XB}}=$ rate of biomass production, $\mathrm{r}_{\mathrm{S}}=$ rate of substrate consumption, $\mathrm{Y}=$ true growth yield, all expressed in the unit of COD which is $\mathrm{mg} / \mathrm{l}$

The rate of biomass production or the growth rate is expressed as a first-order equation:

$\mathrm{r}_{\mathrm{XB}}=\mu \mathrm{X}_{\mathrm{B}}$

$\mu=$ specific growth rate and $X_{B}=$ active biomass concentration.

Combining equations 1 and 2 gives:

$r_{S}=-\mu X_{B} / Y$ 
$=-(\mu / Y) X_{B}$

$\mu / Y$ is described as the specific substrate consumption rate.

Monod equation describes the inter relationship between growth rate and substrate concentrations and it is expressed as:

$\mu=\mu \mathrm{m} \frac{\mathrm{sS}}{\mathrm{KS}+\mathrm{SS}}$

where $\mu_{\mathrm{m}}=$ maximum specific growth rate, $\mathrm{S}_{\mathrm{S}}=$ the substrate concentration and $\mathrm{K}_{\mathrm{S}}=$ half-saturation coefficient for substrate, which is the substrate concentration at half maximum specific growth rate.

Decay: This is the loss of biomass or death of microorganisms. It is described by first order expression similar to growth:

$\mathrm{r}_{\mathrm{XD}}=-\mathrm{bX} \mathrm{B}$

where $\mathrm{b}=$ decay coefficient, $\mathrm{r}_{\mathrm{XD}}=$ reaction rate of biomass decay, $\mathrm{X}_{\mathrm{B}}=$ active biomass concentration.

\subsection{Continuous Bioreactor Dynamics}

The simplest way to model cell growth will be to consider an unstructured, unsegregated model for cell

growth. For this kind of model,

$\mathrm{r}_{\mathrm{x}}=\mathrm{dX} / \mathrm{dt}=\mu \mathrm{X}$

where, $r_{x}=$ rate of cell generation $(\mathrm{g} / \mathrm{l}-\mathrm{hr})$

$\mathrm{X}=$ cell concentration $(\mathrm{g} / \mathrm{l})$

$\mu=$ specific growth rate $\left(\mathrm{hr}^{-1}\right)$

For a continuously fed bioreactor, the cells are continuously supplied substrate at growth limiting level, and hence they remain in the exponential phase. A cell balance on the reactor can be written as:

$F X-F X_{f}+V(d X / d t)=r_{x}$

where, $\mathrm{F}=$ volumetric flow rate of influent $(\mathrm{l} / \mathrm{hr})$

$\mathrm{X}=$ cell concentration inside the reactor and in the outlet stream $(\mathrm{g} / \mathrm{l})$

$\mathrm{X}_{\mathrm{f}}=$ cell concentration in the feed $(\mathrm{g} / \mathrm{l})$

$\mathrm{V}=$ reactor volume $(\mathrm{l})$

For a sterile feed $\left(\mathrm{X}_{\mathrm{f}}=0\right)$, and noting that the reaction rate can be written in terms of the specific growth rate $\left(\mathrm{r}_{\mathrm{x}}=\right.$ $\mu \mathrm{X})$, equation 6 can be reduced to

$\frac{\mathrm{dX}}{\mathrm{dt}}=(\mu-\mathrm{D}) \mathrm{X}$

where $\mathrm{D}=$ dilution rate $=\mathrm{F} / \mathrm{V}\left(\mathrm{hr}^{-1}\right)$

A balance on the substrate yields

$$
\mathrm{FS}-\mathrm{FSf}+\mathrm{V} \frac{\mathrm{dS}}{\mathrm{dt}}=\mathrm{rsV}
$$

where, $\mathrm{F}=$ volumetric flow rate $(\mathrm{l} / \mathrm{hr})$

$\mathrm{S}=$ cell concentration inside the bioreactor and in the outlet stream $(\mathrm{g} / \mathrm{l})$

$\mathrm{S}_{\mathrm{f}}=$ substrate concentration in the feed $(\mathrm{g} / \mathrm{l})$

$\mathrm{V}=$ reactor volume (l)

$\mathrm{r}_{\mathrm{s}}=$ rate of substrate consumption $(\mathrm{g} / \mathrm{l}-\mathrm{hr})$

A yield parameter $\left(\mathrm{Y}_{\mathrm{X} / \mathrm{s}}\right)$ is defined that relates the amount of cell mass produced per amount of substrate consumed, and is mathematically represented as:

$\mathrm{Y}_{\mathrm{x} / \mathrm{s}}=$ mass of cells produced/ mass of substrate consumed $=r_{\mathrm{x}} /-\mathrm{r}_{\mathrm{s}}$

10

Combining equations 6,9 , and 10 yields

$\frac{\mathrm{dS}}{\mathrm{dt}}=\mathrm{D}\left(\mathrm{S}_{\mathrm{f}}-\mathrm{S}\right)-\frac{\mu \mathrm{X}}{\mathrm{Yx} / \mathrm{s}}$

\subsection{Bioreactor Modelling}

The aerobic biofilter is modelled as a continuous stirred tank reactor (CSTR). The stoichiometry of a reaction is specified on a mass basis while the reaction rate is specified by selecting appropriate expressions for the reaction constant $(\mathrm{K})$, substrate term (S-Term), other terms (O-Term) and the biomass term (B-Term). The reaction rate constant of each reaction is specified at a reference temperature and the parameter "Theta $(\theta)$ " that affects the calculation of the rate constant at any temperature is specified too.

The reaction rate is given by

Rate $\left(\frac{\mathrm{mg}}{\mathrm{hr}}\right)=\mathrm{K} \times(\mathrm{S}-$ Term $) \times(\mathrm{O}-$ Term $) \times(\mathrm{B}-$ Term $)$

here $\mathrm{K}=\mathrm{K}_{\text {max }_{0}} \theta^{\mathrm{T}-\mathrm{T}_{0}}$

$\mathrm{K}_{\max _{0}}=0.081 / \mathrm{hr}$

$\mathrm{T}_{\mathrm{O}}=20^{\circ} \mathrm{C}$

$\theta=1.04$

$\mathrm{S}$-Term is Glucose which uses Monod Kinetics,

$\mathrm{KS}=5.00 \mathrm{mg} / \mathrm{l}$

The figure below shows a Continuous Stirred Tank Reactor (CSTR) with an influent and effluent stream and operating at a constant volume. 


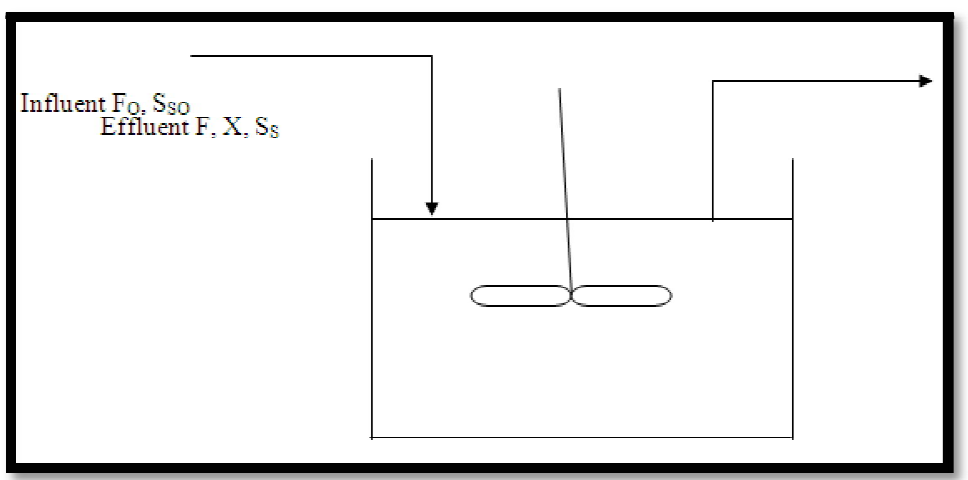

Figure 1: Continuous Stirred Tank Reactors

$\mathrm{F}_{\mathrm{O}}=$ Influent flow rate $(\mathrm{l} / \mathrm{h})$

$\mathrm{F}=$ Effluent flow rate $(\mathrm{l} / \mathrm{h})$

$\mathrm{S}_{\mathrm{so}}=$ Influent substrate concentration $(\mathrm{g} / \mathrm{l})$

$\mathrm{S}_{\mathrm{S}}=$ Effluent substrate concentration $(\mathrm{g} / \mathrm{l})$

So $=$ Dissolved oxygen concentration $(\mathrm{g} / \mathrm{l})$

$\mathrm{X}=$ Biomass concentration $(\mathrm{g} / \mathrm{l})$

$\mathrm{V}=$ Reactor volume $(\mathrm{l})$

The model for the CSTR can be obtained by completing mass balances over the volume control, taken as the reactor volume, V, on: (i) Substrate (ii) Biomass

On substrate:

$$
\mathrm{V} \frac{\mathrm{dS}}{\mathrm{dt}}=\mathrm{F}_{\mathrm{O}} \cdot \mathrm{S}_{\mathrm{so}}-\mathrm{F} \cdot \mathrm{S}_{\mathrm{S}}+\mathrm{r}_{\mathrm{S}} \cdot \mathrm{V}
$$

Where $\mathrm{F}_{\mathrm{O}}$ and $\mathrm{F}$ are the volumetric flow rates for the influent and effluent; $\mathrm{S}_{\mathrm{so}}$ and $\mathrm{S}_{\mathrm{s}}$ are the influent and effluent concentrations in COD respectively [22].

For steady state, the equation simplifies to:

$-r_{\mathrm{S}}=\frac{\mathrm{F}}{\mathrm{V}}\left(\mathrm{S}_{\mathrm{SO}}-\mathrm{S}_{\mathrm{S}}\right)$

The mean Hydraulic Residence Time (HRT) with symbol $\boldsymbol{\tau}$, is the inverse of the dilution rate, D, with $\tau=\frac{\mathrm{V}}{\mathrm{F}}=\frac{1}{\mathrm{D}}$

Combining equations 3 and 14 and replacing with 15, gives:

$$
\begin{array}{rlrl}
\frac{\mathrm{F}}{\mathrm{V}}\left(\mathrm{S}_{\mathrm{SO}}-\mathrm{S}_{\mathrm{S}}\right) & =\mu \frac{\mathrm{X}_{\mathrm{B}}}{\mathrm{Y}} & & \\
:- & \mathrm{X}_{\mathrm{B}} & =\mathrm{Y} \frac{\left(\mathrm{S}_{\mathrm{SO}}-\mathrm{S}_{\mathrm{S}}\right)}{\mu \tau}
\end{array}
$$

On biomass: Completing a mass balance on active biomass concentration at steady state and using equations 2, 5 and 15 with no biomass in the influent; the following equation is obtained:

$$
\begin{array}{ll}
0-\mathrm{FX}_{\mathrm{B}} & +\mathrm{r}_{\mathrm{XB}} \mathrm{V}+\mathrm{r}_{\mathrm{XD}} \mathrm{V}=0 \\
\text { i.e } & -\mathrm{X}_{\mathrm{B}}^{\mathrm{V}}-{ }_{\boldsymbol{\tau}}+\mu \mathrm{X}_{\mathrm{B}} \mathrm{V}-\mathrm{bX} \mathrm{X}_{\mathrm{B}} \mathrm{V}=0 \\
\text { and } & \mu=\frac{1}{\tau+\mathrm{b}}
\end{array}
$$

Equation 18 may be written to define the dilution rate as:

$$
\mathrm{D}=\mu-\mathrm{b}
$$

showing that the growth rate must be faster than the dilution rate by the amount of the decay rate. Substituting $\mu$ in equation 16 with equation 18 gives:

$$
\mathrm{X}_{\mathrm{B}}=\mathrm{Y} \frac{\left(\mathrm{S}_{\mathrm{SO}}-\mathrm{S}_{\mathrm{S}}\right)}{1+\mathrm{b} \tau}
$$

The observed yield is the measured biomass formed per substrate removed taking decay into account and is defined by:

$$
\mathrm{Y}_{\mathrm{obs}}=\frac{\mathrm{X}}{\left(\mathrm{S}_{\mathrm{SO}}-\mathrm{S}_{\mathrm{S}}\right)}
$$

with $\mathrm{X}$ the measured biomass concentration [22].

Assuming negligible biomass debris as part of $\mathrm{X}$ (influenced by $\boldsymbol{\tau}$ ), results in $\mathrm{X}$ being equal to $\mathrm{X}_{\mathrm{B}}$. Combining equations 20 and 21 gives the correlation between $Y$ and $\mathrm{Y}_{\mathrm{obs}}$ :

$$
\mathrm{Y}_{\mathrm{obs}}=\frac{\mathrm{Y}}{(1+\mathrm{b} \tau)}
$$

Equation 3.4 may be rewritten for substrate determination and $\mu$ substituted with equation 18 , giving:

$$
\begin{gathered}
S_{S}=\mu \frac{K_{S}}{\mu_{m-\mu}} \\
=\frac{K_{S} \frac{1}{\tau+b}}{\mu m-\frac{1}{\tau+b}}
\end{gathered}
$$


Most industrial reactors are operated in a continuous mode instead of batch because continuous reactors produce more products with smaller equipment, cheaper, require less labour and maintenance and frequently produce better quality control. Since the reactor is uniform in composition everywhere, an integral mass balance on the number of moles $\mathrm{N}_{\mathrm{A}}$ of species $\mathrm{A}$ in a reactor of volume $\mathrm{V}$ was made:

Accumulation $=[$ flow in $]-[$ flow out $]+[$ generation $]$

$\frac{\mathrm{dN}_{\mathrm{A}}}{\mathrm{dt}}=\mathrm{F}_{\mathrm{A}_{\mathrm{O}}}-\mathrm{F}_{\mathrm{A}}+\mathrm{Vv}_{\mathrm{A}} \mathrm{r}$

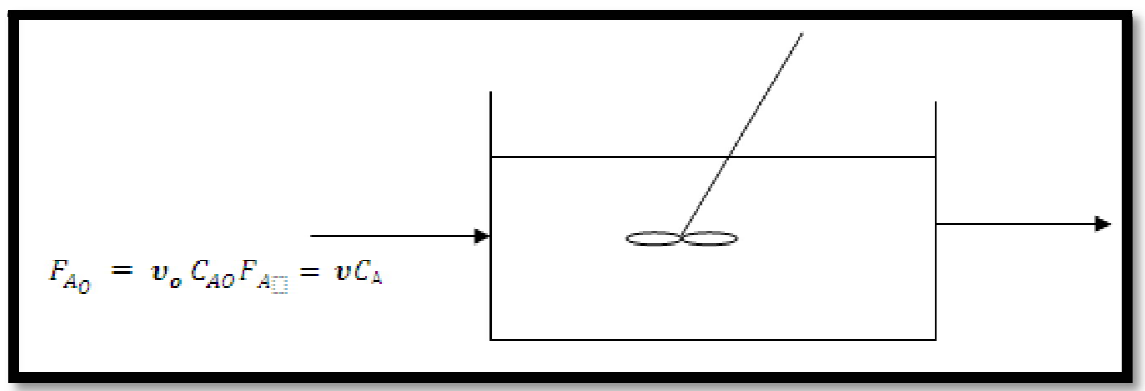

Figure 2: Continuous Stirred Tank Reactors

where $\mathrm{F}_{\mathrm{A}_{\mathrm{O}}} \& \mathrm{~F}_{\mathrm{A}}$ are molar flow rates of species $\mathrm{A}$ (in moles/ time) in the inlet and outlet respectively. If the reactor is completely mixed:

$\mathrm{N}_{\mathrm{A}}$ can be related to $\mathrm{C}_{\mathrm{A}}$ by this relation;

$\mathrm{N}_{\mathrm{A}}=\mathrm{C}_{\mathrm{A}} \mathrm{V}$

where $\mathrm{C}_{\mathrm{A}}=$ concentration of species $\mathrm{A}, \mathrm{V}=$ volume of the reactor, $\mathrm{N}_{\mathrm{A}}=$ number of moles of species $\mathrm{A}$.

Molar flow rates $\mathrm{F}_{\mathrm{A}_{0}}$ and $\mathrm{F}_{\mathrm{A}}$ of species $\mathrm{A}$ can be related to the concentration by the relationships

$\mathrm{F}_{\mathrm{A}_{\mathrm{O}}}=\mathbf{v}_{\mathbf{0}} \mathrm{C}_{\mathrm{AO}}$ and $\mathrm{F}_{\mathrm{A}}=\mathbf{v C}_{\mathrm{A}}$ respectively, where $\mathbf{v}_{\mathbf{0}}$ and $\boldsymbol{v}$ are the volumetric flow rates into and out of the reactor.

For reactions among liquids and among gases where the total number of moles does not change, the density of the system does not change with composition, therefore $\mathbf{v}_{\mathbf{o}}=\mathbf{v}$. If $\mathrm{V}$ is constant and the density does not change with composition differentiation of $\mathrm{N}_{\mathrm{A}}$ yields
$\frac{\mathrm{dN}_{\mathrm{A}}}{\mathrm{dt}}=\mathrm{V} \frac{\mathrm{dC}_{\mathrm{A}}}{\mathrm{dt}}$
26

If the density of the fluid is constant, then the volumetric flow rates in and out of the reactor are equal,

$v=v_{0}$.

The mass balance equation then simplifies to become

$\mathrm{V} \frac{\mathrm{dC}_{\mathrm{A}}}{\mathrm{dt}}=\mathrm{v}\left(\mathrm{C}_{\mathrm{AO}}-\mathrm{C}_{\mathrm{A}}\right)+\mathrm{Vv}_{\mathrm{A}} \mathrm{r}$

Assume steady state system, with this time derivative equal to zero to obtain

$v\left(\mathrm{C}_{\mathrm{AO}}-\mathrm{C}_{\mathrm{A}}\right)+\mathrm{Vv}_{\mathrm{A}} \mathrm{r}=0$

Reactor residence time $\tau=\frac{v}{v}$

Where $\mathrm{V}=$ reactor volume, $\mathbf{v}=$ volumetric flow rate

Therefore, the steady - state mass balance on species A in the CSTR can be written as;

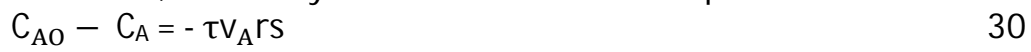

The bioreactor in series is modelled using the following assumptions:

- constant density (valid for most liquids; valid for gases only if there is no net change in the number of moles or drastic temperature change)

- isothermal conditions

- steady state

- $\quad$ single, irreversible reaction $\left(v_{\mathrm{A}}=-1\right)$

- first-order reaction $\left(\mathrm{r}=\mathrm{kC}_{\mathrm{A}}\right)$

- For a reactant species $\mathrm{A}\left(\mathrm{v}_{\mathrm{A}}=-1\right)$ the steady - state mass balance becomes

$$
\mathrm{C}_{\mathrm{AO}}-\mathrm{C}_{\mathrm{A}}=\tau \mathrm{r}\left(\mathrm{C}_{\mathrm{A}}\right)
$$

For nth - order irreversible reaction

$$
\text { A } \longrightarrow \text { products }
$$

For first - order kinetics, $\mathrm{n}=1$, the mass balance becomes

$$
\begin{aligned}
& \mathrm{C}_{\mathrm{AO}}-\mathrm{C}_{\mathrm{A}}=\tau \mathrm{kC}_{\mathrm{A}} \\
& \mathrm{C}_{\mathrm{AO}}=\mathrm{C}_{\mathrm{A}}+\tau \mathrm{k} \mathrm{C}_{\mathrm{A}}
\end{aligned}
$$

$\mathrm{C}_{\mathrm{AO}}=\mathrm{C}_{\mathrm{A}}(1+\tau \mathrm{k})$

Solving for $\mathrm{C}_{\mathrm{A}}$

$$
\mathrm{C}_{\mathrm{A}}=\frac{\mathrm{C}_{\mathrm{AO}}}{(1+\tau \mathrm{k})}
$$

Where $\mathrm{C}_{\mathrm{A}}=$ final concentration of species $\mathrm{A}, \mathrm{C}_{\mathrm{AO}}=$ initial concentration of species $\mathrm{A}, \mathrm{k}=$ reaction rate constant, $\tau=$ residence time. The values of the variables, outlet concentration and residence time, in Equation 34 are major design 
criteria. Bioreactors in series are shown in Figure 3 below, $\mathrm{C}_{\mathrm{A} 0}$ is the feed to the first tank, while $\mathrm{C}_{\mathrm{A} 3}$, the effluent from the third tank is the feed to ultrafilter. The concentrations $\mathrm{C}_{\mathrm{A}}$ from the nth reactor are obtained by solving each reactor mass balance successively.

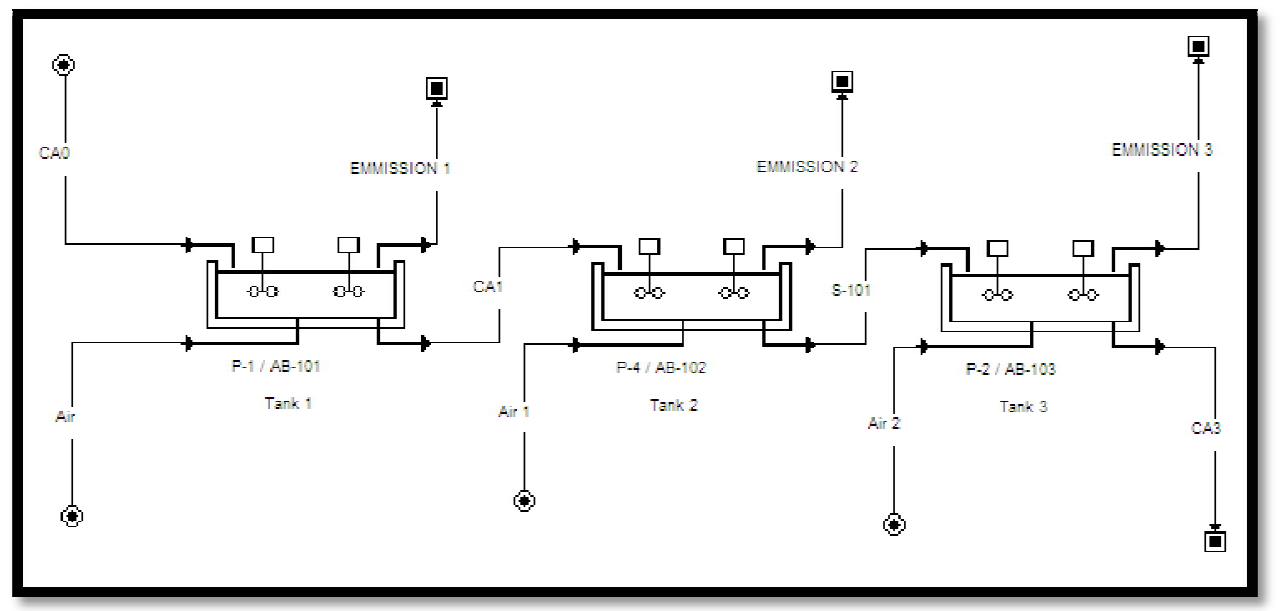

Figure 3: Bioreactors (CSTRs) in series

Model Equations for Bioreactors in series;

For first - order kinetics with equal - volume CSTR reactors, the mass balances on species A become

$\mathrm{C}_{\mathrm{AO}}-\mathrm{C}_{\mathrm{A} 1}=\tau_{1} \mathrm{r}\left(\mathrm{C}_{\mathrm{A} 1}\right)$

$\mathrm{C}_{\mathrm{A} 1}-\mathrm{C}_{\mathrm{A} 2}=\tau_{2} \mathrm{r}\left(\mathrm{C}_{\mathrm{A} 2}\right)$ 35

$\mathrm{C}_{\mathrm{A} 2}-\mathrm{C}_{\mathrm{A} 3}=\tau_{3} \quad \mathrm{r}\left(\mathrm{C}_{\mathrm{A} 3}\right)$ 36

$\mathrm{C}_{\mathrm{A}, \mathrm{n}-1}-\mathrm{C}_{\mathrm{An}}=\tau_{\mathrm{n}} \quad \mathrm{r}\left(\mathrm{C}_{\mathrm{An}}\right)$

37

First Reactor:

$$
\mathrm{C}_{\mathrm{A} 1}=\frac{\mathrm{C}_{\mathrm{AO}}}{\left(1+\mathrm{K} \tau_{1}\right)}
$$

Where $\mathrm{C}_{\mathrm{AO}}=$ feed to the first tank $(\mathrm{g} / \mathrm{L})$

$\mathrm{K}=$ reaction rate constant $\left(\mathrm{hr}^{-1}\right)$

$\tau_{1}=$ residence time for the first tank (hr)

Second Reactor:

$\mathrm{C}_{\mathrm{A} 2}=\frac{\mathrm{C}_{\mathrm{A} 1}}{1+\mathrm{K} \tau_{2}}=\frac{\mathrm{C}_{\mathrm{AO}}}{\left(1+\mathrm{K} \mathrm{K}_{1}\right)\left(1+\mathrm{K}_{\tau 2}\right)}$

Where $\mathrm{C}_{\mathrm{A} 1}=$ effluent from the first tank $(\mathrm{g} / \mathrm{L})$

$\mathrm{C}_{\mathrm{A} 2}=$ effluent from the second tank $(\mathrm{g} / \mathrm{L})$

$\mathrm{K}=$ reaction rate constant $\left(\mathrm{hr}^{-1}\right)$

$\tau_{2}=$ residence time for the second tank $(\mathrm{hr})$

Third Reactor:

$\mathrm{C}_{\mathrm{A} 3}=\frac{\mathrm{C}_{\mathrm{A} 2}}{1+\mathrm{K}_{3}}=\frac{\mathrm{C}_{\mathrm{AO}}}{\left(1+\mathrm{K \tau}_{1}\right)\left(1+\mathrm{K}_{\tau 2}\right)\left(1+\mathrm{K}_{\tau 3}\right)}$

Where $\mathrm{C}_{\mathrm{A} 2}=$ effluent from the second tank $(\mathrm{g} / \mathrm{L})$

$\mathrm{C}_{\mathrm{A} 3}=$ effluent from the third tank $(\mathrm{g} / \mathrm{L})$

$\mathrm{k}=$ reaction rate constant $\left(\mathrm{hr}^{-1}\right)$

$\tau_{3}=$ residence time for the third tank $(\mathrm{hr})$

Each reactor has the same residence time $\tau$ (all reactors have the same volume),

then the total residence time $\tau_{\text {total }}$ in the series of $n$ equal-residence-time CSTRs is $\tau_{\text {total }}=n \tau$.

Total Material Balance

In order to formulate a feasible mathematical model of biofiltration, several simplifying assumptions have to be made. The assumptions of the model are as follows:

- Biomass distribution and density are assumed to be homogeneous.

- Rate of the substrate consumption by microorganisms follows first order kinetics.

- Carbondioxide production follows the stoichiometric relationship i.e.

Glucose

$$
\longrightarrow \text { biomass }+\mathrm{H}_{2} \mathrm{O}+\mathrm{CO}_{2} \text {, and }
$$

Benzene

- Initial $\mathrm{CO}_{2}$ concentration in biofilter is zero.

In a CSTR, the total material balance can be given as:

INPUT + PRODUCTION = OUTPUT + ACCUMULATION

That is:

$F_{O} . S_{s o}+r_{s} . V=F$. Ss $+\frac{d n S}{d t}$

where $\mathrm{F}_{\mathrm{O}}=$ Influent flow rate, $\mathrm{F}=$ Effluent flow rate, $\mathrm{S}_{\mathrm{SO}}=$ =Influent substrate concentration, 
$\mathrm{S}_{\mathrm{S}}=$ Effluent substrate concentration, $\mathrm{V}=$ Reactor volume, $\mathrm{n}_{\mathrm{S}}=$ numberof moles of substrate,

$\mathrm{n}_{\mathrm{s}}=\mathrm{VS}$

In an open system we can never reach a chemical equilibrium. We can, however, reach a steady state where all state variables (temperature, concentrations etc.) remain constant. This implies that Accumulation $=0$.

Therefore, equation 42 becomes:

$\mathrm{F}_{\mathrm{O}} \cdot \mathrm{S}_{\mathrm{SO}}=\mathrm{F} . \mathrm{S}$

\subsection{Component material balances}

All important components require a component balance.

Rate of flow of components in =rate of flow of components out

For Aeration Tank 1, the component material balance is

$\mathrm{F}_{11} \cdot \mathrm{S}_{\mathrm{S} 11}=\mathrm{F}_{12} \cdot \mathrm{S}_{12}$

For Aeration Tank 2, the component material balance is

$\mathrm{F}_{21} \cdot \mathrm{S}_{\mathrm{S} 21}=\mathrm{F}_{22} \cdot \mathrm{S}_{22}$

For Aeration Tank 3, the component material balance is

$\mathrm{F}_{31} \cdot \mathrm{S}_{\mathrm{s} 31}=\mathrm{F}_{32} \cdot \mathrm{S}_{32}$

For Ultrafilter, the component material balance is

$\mathrm{F}_{\mathrm{U} 1}$. $\mathrm{S}_{\mathrm{SU} 1}=\mathrm{F}_{\mathrm{U} 2}$. $\mathrm{S}_{\mathrm{U} 2}$

For Clarifier, the component material balance is

$\mathrm{F}_{\mathrm{C} 1} \cdot \mathrm{S}_{\mathrm{SC} 1}=\mathrm{F}_{\mathrm{C} 2} \cdot \mathrm{S}_{\mathrm{C} 2}$

\subsection{Process Description}

The process flow diagram is shown in Figure 4, in which the influent (abattoir wastewater) stream is sent to a sequence of three aeration basins (AB-101, AB-102 and AB-103) for biological oxidation of the organic material. Each aeration basin operates at an average hydraulic residence time of 2 hours. A surface aeration system is used to maintain minimum dissolved oxygen (DO) concentration of $2 \mathrm{mg} / \mathrm{l}$. The liquid effluent from the third aeration basin (AB-103) is further treated using an ultrafilter to separate suspended solids and solutes of high molecular weight from water and low molecular weight solutes. The effluent from ultrafilter is sent into a clarifier. The product from the clarifier (CL-101) is sent to the storage tank, which is used to remove the biomass and thicken it to around $10 \mathrm{~g} / \mathrm{l}$ solids content. Plant operation mode is continuous. The annual operating time is 7920 hours and the operating days per year is 330 .

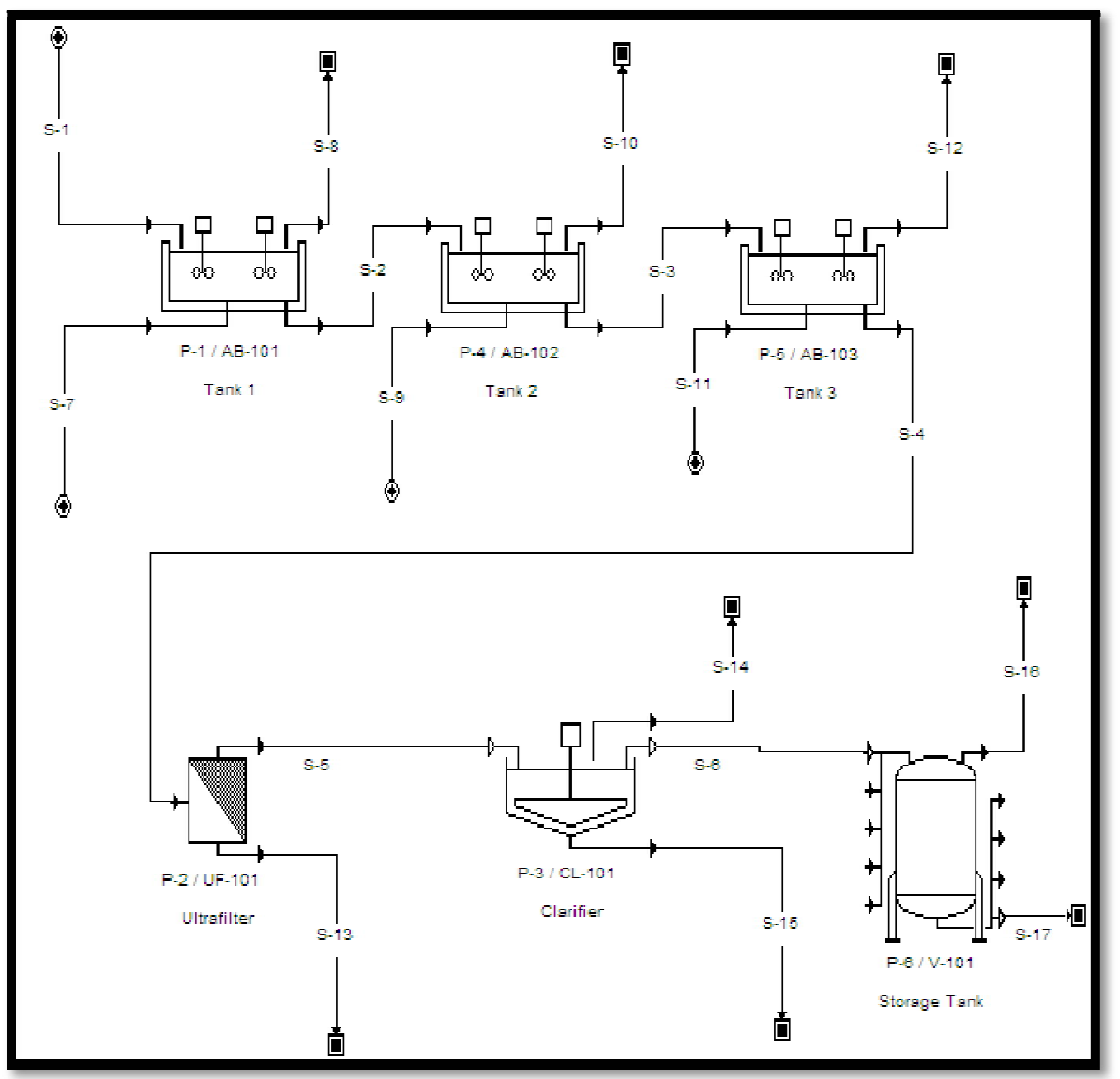

Figure 4: Process Flow Diagram for the Biofilter

Stoichiometry and Kinetics of Bio-Transformations Using Superpro Software

a. Main Substrate (Glucose) Degradation (The Stoichiometry Is On A Mass Basis) 
Glucose $\Longrightarrow$ Biomass $+\mathrm{H}_{2} \mathrm{O}+\mathrm{CO}_{2}$

$$
\begin{array}{llll}
1 \mathrm{~g} & 0.4 \mathrm{~g} & 0.3 \mathrm{~g} & 0.3 \mathrm{~g}
\end{array}
$$

Yield coefficient $Y=0.4 \mathrm{mg}$ Biomass $/ \mathrm{mg}$ Glucose

$\mathrm{k}_{\max _{0}=} 0.08 \mathrm{hr}^{-1}$ at $\mathrm{T}_{0=} 20^{\circ} \mathrm{C}$

theta $=1.04$ (to account for the impact of temperature variations).

$\mathrm{K}_{\mathrm{s}}=5 \mathrm{mg}$ Glucose/ L

b. Benzene reduction (the stoichiometry is on a mass basis)

Benzene $\Longrightarrow$ Biomass $+\mathrm{H}_{2} \mathrm{O}+\mathrm{CO}_{2}$

$$
\begin{array}{llll}
1 \mathrm{~g} & 0.3 \mathrm{~g} & 0.4 \mathrm{~g} & 0.3 \mathrm{~g}
\end{array}
$$

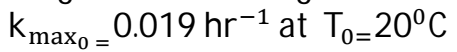

$\mathrm{K}_{\mathrm{s}}=13.571 \mathrm{mg}$ Benzene / L

c. Biomass decay

Biomass $\Longrightarrow$ DeadBiomass

$1 \mathrm{~g} \quad 1 \mathrm{~g}$

$\mathrm{k}=0.005$

51

\section{Results and Discussion}

Simulations were run using the SuperPro software for complete organic matter removal from the abattoir wastewater without polluting the environment. A model was developed for a system in which a biofilter system was used in treating benzene contained in an abattoir wastewater. The same system was simulated using SuperPro Designer 4.53. Benzene was chosen as the component to be studied because it is highly poisonous, not easily biodegradable and volatile. The simulation of the biofilter system was run by first installing three bioreactors in series (with the entire feed streams, that is, benzene, glucose, biomass and water) followed by the ultrafilter, the clarifier and finally the storage tank. The effects, which varying benzene concentration from 100,75 , and 50 to $25 \%$ have on other components were considered. The model values were obtained using Equations 39, 40 and 41 for tanks 1, 2 and 3 respectively. Figures 5 to 8 showed the four design configurations which involved feed inlet streams of glucose, biomass, benzene and water with four different loads of benzene concentrations, which were 100, 75, 50 and 25\% while other components have constant concentration. The simulation for these configurations with their individual specifications in biofilter system was carried out. Disturbances in benzene concentrations were used to test the effectiveness of the proposed biofilter design configuration.

\begin{tabular}{|c|c|c|c|c|c|c|c|c|c|c|}
\hline \multirow{2}{*}{$\begin{array}{l}\text { STREAM } \\
\text { DESTINATION }\end{array}$} & INPUT & P-1 & P-4 & P-5 & P-2 & -3 & \multicolumn{2}{|c|}{ P-4 } & \multicolumn{2}{|c|}{ P-3 } \\
\hline & P-1 & P-4 & P-5 & P-2 & P-3 & OUTPUT & OUTPUT & OUTPUT & OUTPUT & OUTPUT $\mid$ \\
\hline \multicolumn{11}{|c|}{ STREAM PROPERTIES } \\
\hline Temp $\left({ }^{\circ} \mathrm{C}\right)$ & 25.000 & 25.000 & 25.000 & 25.000 & 25.700 & 25.700 & 25.000 & 25.000 & 25.700 & 25.700 \\
\hline Pressure (bar) & 1.000 & 1.000 & 1.000 & 1.000 & 1.000 & 1.000 & 1.000 & 1.000 & 1.000 & 1.000 \\
\hline Density $(g / L)$ & 995.376 & 995.036 & 994.770 & 994.763 & 994.473 & 994.452 & 1.927 & 1.799 & 994.663 & 994.828 \\
\hline \multicolumn{11}{|c|}{ COMPONENT FLOWRATES (kg/h averaged) } \\
\hline Benzene & 100.000 & 47.500 & 31.500 & 0.000 & 0.000 & 0.000 & 12.938 & 0.000 & 0.000 & 0.000 \\
\hline Biomass & 15.660 & 221.404 & 198.017 & 176.801 & 50.515 & 0.505 & 0.000 & 0.000 & 126.286 & 50.009 \\
\hline $\mathrm{CO}_{2}$ & 0.000 & 0.000 & 0.000 & 0.000 & 0.000 & 0.000 & 180.745 & 0.001 & 0.000 & 0.000 \\
\hline Dead Biomass & 0.000 & 26.568 & 50.380 & 71.596 & 20.456 & 0.205 & 0.000 & 0.000 & 51.140 & 20.251 \\
\hline Glucose & 783.000 & 267.333 & 0.000 & 0.000 & 0.000 & 0.000 & 0.000 & 0.000 & 0.000 & 0.000 \\
\hline Water & 156600.000 & 156789.427 & 157056.579 & 157056.579 & 125768.222 & 118848.741 & 0.000 & 0.000 & 31288.357 & 6919.481 \\
\hline TOTAL $(\mathrm{kg} / \mathrm{h})$ & 157498.660 & 157304.977 & 157304.976 & 157304.976 & 125839.191 & 118849.451 & 193.683 & 0.001 & 31465.783 & 6989.741 \\
\hline TOTAL (L/h) & 158230.317 & 158089.734 & 158132.006 & 158133.119 & 126538.570 & 119512.506 & 100510.119 & 0.556 & 31634.617 & 7026.080 \\
\hline
\end{tabular}
The results are shown in the following Tables and Figures below:

Table 2: Component Balance and Stream Report at 100\% Influents 


\begin{tabular}{|c|c|c|c|c|c|c|}
\hline Stream & Benzene & Biomass & Co $_{2}$ & Deadbiomass & Glucose & Water \\
\hline S-1 & 0.632 & 0.099 & 0.000 & 0.000 & 4.948 & 989.697 \\
\hline S-2 & 0.300 & 1.400 & 0.000 & 0.168 & 1.691 & 991.775 \\
\hline S-3 & 0.200 & 1.252 & 0.000 & 0.319 & 0.500 & 993.199 \\
\hline S-4 & 0.000 & 1.118 & 0.000 & 0.453 & 0.000 & 993.192 \\
\hline S-5 & 0.000 & 0.399 & 0.000 & 0.162 & 0.000 & 993.912 \\
\hline S-6 & 0.000 & 0.004 & 0.000 & 0.002 & 0.000 & 994.446 \\
\hline S-8 & 0.129 & 0.000 & 1.798 & 0.000 & 0.000 & 0.000 \\
\hline S-10 & 0.000 & 0.000 & 1.798 & 0.000 & 0.000 & 0.000 \\
\hline S-13 & 0.000 & 3.992 & 0.000 & 1.617 & 0.000 & 989.054 \\
\hline S-15 & 0.000 & 7.118 & 0.000 & 2.882 & 0.000 & 984.828 \\
\hline
\end{tabular}

Table 3: Mass Concentration for the Components (G/ L) at 100\% Benzene

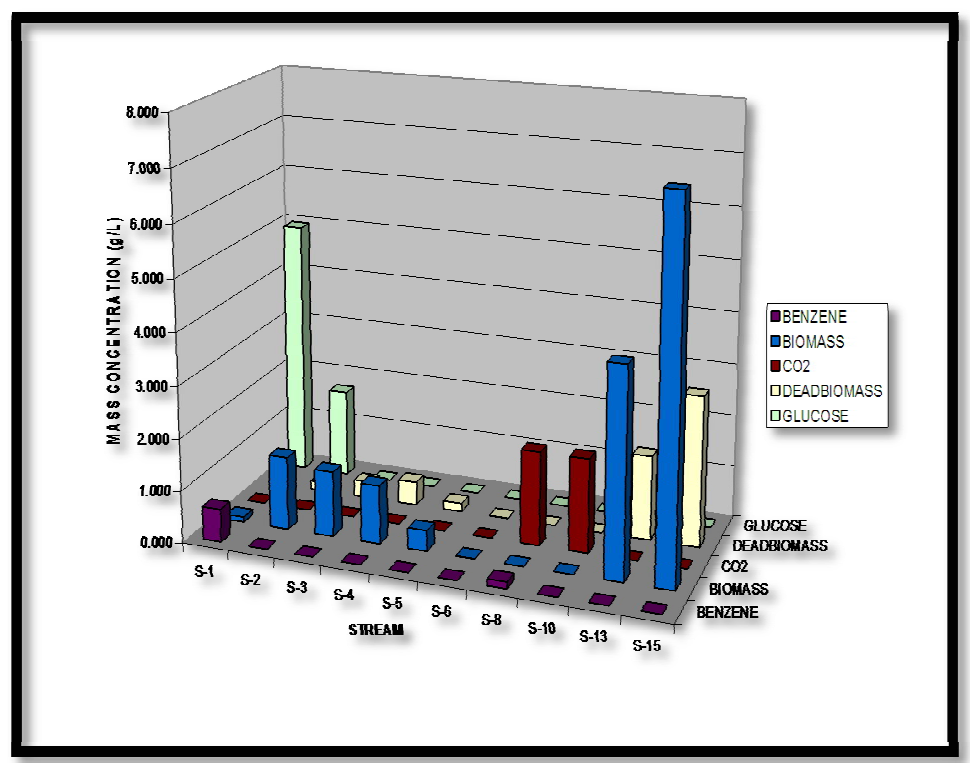

Figure 5: Mass Concentration of Components at 100\% Influents

The figure above showed that at 100\% influents of abattoir wastewater, stream S-1 contained benzene that was introduced into the first aeration tank (S-2) at $0.632 \mathrm{~g} / \mathrm{l}$, which later reduced to $0.300 \mathrm{~g} / \mathrm{l}$ in the second aeration tank (S-3) and to $0.002 \mathrm{~g} / \mathrm{l}$ in the third tank (S-4) as revealed in equation 50 that is, benzene degradation. Biological oxidation of organic contaminants took place in these three tanks. $0.000 \mathrm{~g} / \mathrm{l}$ was released into the ultrafilter (S-5) and $0.000 \mathrm{~g} / \mathrm{l}$ came out from the clarifier (S-6). $0.129 \mathrm{~g} / \mathrm{l}$ (S-8) was emitted from the first tank and nothing came out from the second tank (S10) as emission. Also, biomass of $0.099 \mathrm{~g} / \mathrm{l}$ entered into the first tank and was increased to $1.400 \mathrm{~g} / \mathrm{l}$ because of biomass generation in equations 49 and 50 which later reduced to $1.252 \mathrm{~g} / \mathrm{l}$ because of biomass decay to deadbiomass and further reduction took place in ultrafilter to $0.004 \mathrm{~g} / \mathrm{l}$ where there was separation of suspended sludge and solutes of high molecular weight from solutes of low molecular weight through a semi permeable. Since biomass is not a gas, it came out as a sludge in both ultrafilter and clarifier that is, $3.992 \mathrm{~g} / \mathrm{l}$ in S-13 and 7.118g/ $\mathrm{l}$ in S-15 respectively.

$\mathrm{CO}_{2}$ was not initially introduced into the biofilter, but later generated from glucose and benzene degradations in equations 49 and 50 respectively. Deadbiomass was not introduced into the system initially, but it was later generated from biomass decay in equation 51 . Glucose came in at $4.948 \mathrm{~g} / \mathrm{l}$ and later reduced to $0.000 \mathrm{~g} / \mathrm{l}$, no glucose came out as sludge. However, water of $995.990 \mathrm{~g} / \mathrm{L}$ concentration entered as input in S-1 as the major component and remained almost constant 


\begin{tabular}{|c|c|c|c|c|c|c|c|c|c|c|c|}
\hline STREAMNAME & S-1 & S-2 & S-3 & S-4 & S-5 & S-6 & S-8 & S-10 & S-12 & S-13 & S-15 \\
\hline \multicolumn{12}{|c|}{ STREAM PROPERTIES } \\
\hline Temp ("C) & 25.000 & 25.000 & 25.000 & 25.000 & 25.700 & 5.700 & 25.000 & 25.000 & 25.000 & 25.700 & 25.700 \\
\hline Density $(g / L)$ & 995.398 & 995.093 & 994.802 & 994.791 & 994.483 & 994.452 & 1.883 & 1.799 & 1.824 & 994.762 & 994.846 \\
\hline \multicolumn{12}{|c|}{ COMPONENT FLOWRATES (kg/h averaged) } \\
\hline Benzene & 75.000 & 0.137 & 0.000 & 0.000 & 0.000 & 0.000 & 7.246 & 0.002 & 0.002 & 0.000 & 0.000 \\
\hline Biomass & 15.660 & 191.401 & 290.989 & 260.084 & 74.310 & 0.743 & 0.000 & 0.000 & 0.000 & 185.774 & 73.567 \\
\hline Water & 156600.000 & 156760.865 & 156861.769 & 156862.004 & 125662.138 & 115934.964 & 0.000 & 0.000 & 0.000 & 31199.866 & 9727.174 \\
\hline TOTAL (kg/h) & 157473.660 & 157312.310 & 157211.418 & 157211.186 & 125761.904 & 115935.962 & 161.349 & 100.892 & 0.232 & 31449.281 & 9825.943 \\
\hline TOTAL (L/h) & 158201.704 & 158088.048 & 158032.873 & 158034.387 & 126459.582 & 116582.763 & 85687.201 & 56082.268 & 127.671 & 31614.880 & 9876.848 \\
\hline
\end{tabular}

Table 4: Component Balance and Stream Report at 75\% Benzene

\begin{tabular}{|c|c|c|c|c|c|c|}
\hline Stream & Benzene & Biomass & $\mathbf{C o}_{\mathbf{2}}$ & Deadbiomass & Glucose & Water \\
\hline S-1 & 0.474 & 0.099 & 0.000 & 0.000 & 4.949 & 989.876 \\
\hline S-2 & 0.001 & 1.211 & 0.000 & 0.145 & 2.131 & 991.605 \\
\hline S-3 & 0.000 & 1.841 & 0.000 & 0.366 & 0.005 & 992.590 \\
\hline S-4 & 0.000 & 1.646 & 0.000 & 0.564 & 0.000 & 992.581 \\
\hline S-5 & 0.000 & 0.588 & 0.000 & 0.201 & 0.000 & 993.694 \\
\hline S-6 & 0.000 & 0.006 & 0.000 & 0.002 & 0.000 & 994.443 \\
\hline S-8 & 0.085 & 0.000 & 1.798 & 0.000 & 0.000 & 0.000 \\
\hline S-10 & 0.000 & 0.000 & 1.799 & 0.000 & 0.000 & 0.000 \\
\hline S-12 & 0.025 & 0.000 & 0.230 & 0.000 & 0.000 & 0.000 \\
\hline S-13 & 0.000 & 5.876 & 0.000 & 2.013 & 0.000 & 986.873 \\
\hline S-15 & 0.000 & 7.448 & 0.000 & 2.552 & 0.000 & 984.846 \\
\hline
\end{tabular}

Table 5: Mass Concentration for the Components (G/ L) at 75\% Benzene

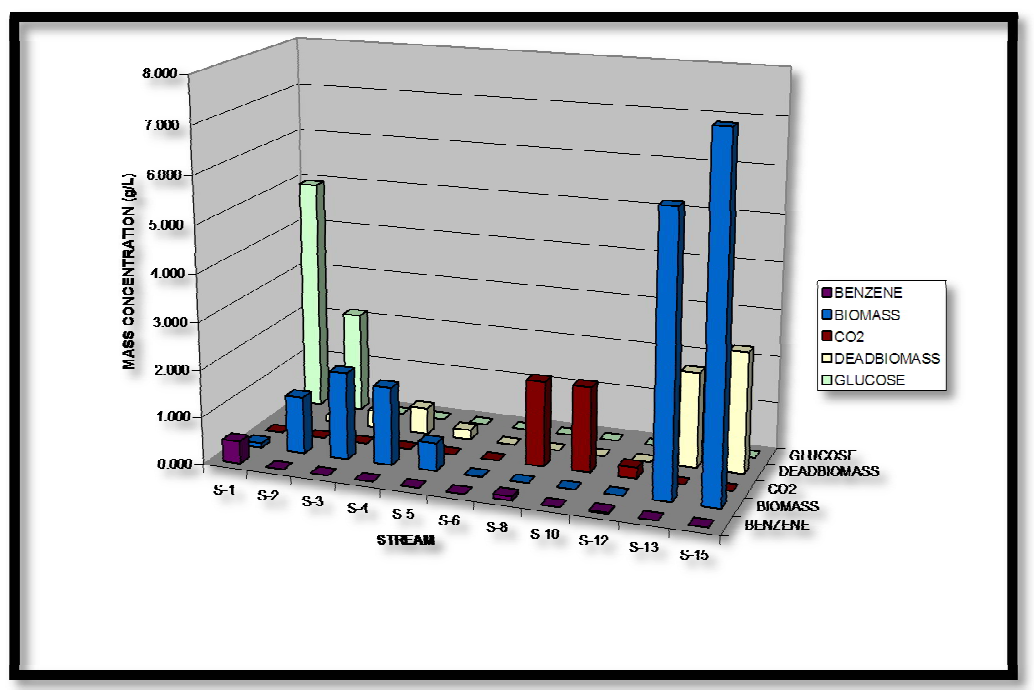

Figure 6: Mass Concentration of Components at 75\% Benzene

The figure above showed that at 75\% influents of benzene, stream S-1 contained benzene that was introduced into the first aeration tank at $0.474 \mathrm{~g} / \mathrm{l}$, which later reduced to $0.001 \mathrm{~g} / \mathrm{l}$ in the second aeration tank and to $0.000 \mathrm{~g} / \mathrm{l}$ in the third tank as revealed in equation 50 that is, benzene degradation. Biological oxidation of organic contaminants took place in these three tanks. $0.000 \mathrm{~g} / \mathrm{l}$ was released into the ultrafilter and $0.000 \mathrm{~g} / \mathrm{l}$ came out from the clarifier. $0.085 \mathrm{~g} / \mathrm{l}$ (S-8) was emitted from the first tank and $0.025 \mathrm{~g} / \mathrm{l}$ came out from the third tank (S-12) as emission. Also, biomass of $0.099 \mathrm{~g} / \mathrm{l}$ entered into the first tank and was increased to $1.211 \mathrm{~g} / \mathrm{l}$ because of biomass generation in equations 49 and 50 which later increased to $1.646 \mathrm{~g} / \mathrm{l}$ in the third tank because of biomass generation from glucose and benzene degradations and biomass reduction took place in ultrafilter to $0.588 \mathrm{~g} / \mathrm{l}$ where there was separation of suspended sludge and solutes of high molecular weight from solutes of low molecular weight through a semi permeable and $0.006 \mathrm{~g} / \mathrm{l}$ came out from the 
clarifier. Since biomass is not a gas, it came out as sludge in both ultrafilter and clarifier that is, $5.876 \mathrm{~g} / \mathrm{l}$ in S-13 and $7.448 \mathrm{~g} / \mathrm{l}$ in S-15 respectively. $\mathrm{CO}_{2}$ was not initially introduced into the biofilter, but later generated from glucose and benzene degradations in equations 49 and 50 respectively.

Deadbiomass was not introduced into the system initially, but it was later generated from biomass decay in equation 51 . Glucose came in at $4.949 \mathrm{~g} / \mathrm{l}$ and later reduced to $0.005 \mathrm{~g} / \mathrm{l}$, no glucose came out as sludge. However, water of $989.900 \mathrm{~g} / \mathrm{L}$ concentration entered as input in S-1 as the major component and remained almost constant.

\begin{tabular}{|c|c|c|c|c|c|c|c|c|c|c|c|}
\hline STREAM NAME & S-1 & S-2 & S-3 & S-4 & S-5 & S-6 & S-8 & S-10 & S-12 & S-13 & S-15 \\
\hline SOURCE & INPUT & P-1 & P-4 & P-5 & P-2 & P-3 & P-1 & P-4 & P-5 & P-2 & P-3 \\
\hline DESTINATION & P-1 & P-4 & P-5 & P-2 & P-3 & OUTPUT & OUTPUT & OUTPUT & OUTPUT & OUTPUT & OUTPUT \\
\hline \multicolumn{12}{|c|}{ STREAM PROPERTIES } \\
\hline Temp ( $\left.{ }^{(} \mathrm{C}\right)$ & 25.000 & 25.000 & 25.000 & 25.000 & 25.700 & 25.700 & 25.000 & 25.000 & 25.000 & 25.700 & 25.700 \\
\hline Pressure (bar) & 1.000 & 1.000 & 1.000 & 1.000 & 1.000 & 1.000 & 1.000 & 1.000 & 1.000 & 1.000 & 1.000 \\
\hline Density $(\mathrm{g} / \mathrm{L})$ & 995.420 & 995.158 & 994.770 & 994.790 & 994.482 & 994.452 & 1.853 & 1.799 & 1.826 & 994.760 & 994.850 \\
\hline \multicolumn{12}{|c|}{ COMPONENT FLOWRATES (kg/h averaged) } \\
\hline Benzene & 50.000 & 0.072 & 0.000 & 0.000 & 0.000 & 0.000 & 3.789 & 0.001 & 0.006 & 0.000 & 0.000 \\
\hline Biomass & 15.660 & 157.440 & 288.683 & 258.207 & 73.773 & 0.738 & 0.000 & 0.000 & 0.000 & 184.433 & 73.036 \\
\hline $\mathrm{CO}_{2}$ & 0.000 & 0.000 & 0.000 & 0.000 & 0.000 & 0.000 & 123.965 & 124.419 & 0.381 & 0.000 & 0.000 \\
\hline Dead Biomass & 0.000 & 18.893 & 53.535 & 84.520 & 24.149 & 0.242 & 0.000 & 0.000 & 0.000 & 60.371 & 23.907 \\
\hline Glucose & 783.000 & 415.921 & 1.262 & 0.000 & 0.000 & 0.000 & 0.000 & 0.000 & 0.000 & 0.000 & 0.000 \\
\hline Water & 156600.000 & 156728.579 & 156853.005 & 156853.372 & 125651.964 & 116104.574 & 0.000 & 0.000 & 0.000 & 31201.408 & 9547.390 \\
\hline TOTAL (kg/h) & 157448.660 & 157320.905 & 157196.485 & 157196.099 & 125749.886 & 116105.554 & 127.754 & 124.420 & 0.387 & 31446.212 & 9644.333 \\
\hline TOTAL (L/h) & 158173.093 & 158086.360 & 158022.945 & 158019.380 & 26447.6241 & 16753.301 & 68944.414 & 69160.645 & 212.006 & 31611.858 & 9694.258 \\
\hline
\end{tabular}

Table 6: Component Balance and Stream Report at 50\% Benzene

\begin{tabular}{|c|c|c|c|c|c|c|}
\hline Stream & Benzene & Biomass & $\mathbf{C o}_{2}$ & Deadbiomass & Glucose & Water \\
\hline S-1 & 0.316 & 0.099 & 0.000 & 0.000 & 4.950 & 990.055 \\
\hline S-2 & 0.000 & 0.996 & 0.000 & 0.120 & 2.631 & 991.411 \\
\hline S-3 & 0.000 & 1.827 & 0.000 & 0.339 & 0.008 & 992.628 \\
\hline S-4 & 0.000 & 1.634 & 0.000 & 0.535 & 0.000 & 992.621 \\
\hline S-5 & 0.000 & 0.583 & 0.000 & 0.191 & 0.000 & 993.708 \\
\hline S-6 & 0.000 & 0.006 & 0.000 & 0.002 & 0.000 & 994.444 \\
\hline S-8 & 0.055 & 0.000 & 1.798 & 0.000 & 0.000 & 0.000 \\
\hline S-10 & 1.798 & 0.000 & 1.799 & 0.000 & 0.000 & 0.000 \\
\hline S-12 & 0.027 & 0.000 & 1.798 & 0.000 & 0.000 & 0.000 \\
\hline S-13 & 0.000 & 5.834 & 0.000 & 1.910 & 0.000 & 987.016 \\
\hline S-15 & 0.000 & 7.534 & 0.000 & 2.466 & 0.000 & 984.850 \\
\hline
\end{tabular}

Figure 7: Mass Concentration of Components at 50\% Benzene

The figure above showed that at $50 \%$ influents of benzene, stream S-1 contained benzene that was introduced into the first aeration tank at $0.316 \mathrm{~g} / \mathrm{l}$, which later reduced to $0.000 \mathrm{~g} / \mathrm{l}$ in the second aeration tank and to $0.000 \mathrm{~g} / \mathrm{l}$ in the third tank as revealed in equation 50. Biological oxidation of organic contaminants took place in these three tanks. $0.000 \mathrm{~g} / \mathrm{l}$ was released into the ultrafilter and $0.000 \mathrm{~g} / \mathrm{l}$ came out from the clarifier. $0.055 \mathrm{~g} / \mathrm{l}$ (S-8) was emitted from the first tank and $1.798 \mathrm{~g} / \mathrm{l}$ came out from the second tank as emission and $0,027 \mathrm{~g} / \mathrm{l}$ was out from the third tank. Also, biomass of $0.099 \mathrm{~g} / \mathrm{l}$ entered into the first tank and was increased to $1.827 \mathrm{~g} / \mathrm{l}$ because of biomass generation in equations 49 and 50 which later reduced to $1.634 \mathrm{~g} / \mathrm{l}$ because of biomass decay to deadbiomass and further reduction took place in ultrafilter to $0.583 \mathrm{~g} / \mathrm{l}$ where there was separation of suspended sludge and solutes of high molecular weight from solutes of low molecular weight through a semi permeable. Since biomass is not a gas, it came out as a sludge in both ultrafilter and clarifier that is, $5.834 \mathrm{~g} / \mathrm{l}$ in S-13 and $7.534 \mathrm{~g} / \mathrm{l}$ in S-15 respectively.

$\mathrm{CO}_{2}$ was not initially introduced into the biofilter, but later generated from glucose and benzene degradations in equations 49 and 50 respectively and it was emitted in S-8, S-10 and S-12 in the first, second and third tank as 1.798, 1.799 and $1.798 \mathrm{~g} / \mathrm{l}$ respectively. Deadbiomass was not introduced into the system initially, but it was later generated from biomass decay in equation 51 . Glucose came in at $4.950 \mathrm{~g} / \mathrm{l}$ and later reduced to $0.008 \mathrm{~g} / \mathrm{l}$, no glucose came out as sludge. However, water of $990.000 \mathrm{~g} / \mathrm{L}$ concentration entered as input in S-1 as the major component and remained almost constant. 


\begin{tabular}{|c|c|c|c|c|c|c|c|c|c|c|c|}
\hline STREAMNAMES & S-1 & S-2 & S-3 & S-4 & S-5 & S-6 & S-8 & S-10 & S-12 & S-13 & S-15 \\
\hline SOURCE & INPUT & P-1 & P-4 & P-5 & P-2 & P-3 & P-1 & P-4 & P-5 & P-2 & P-3 \\
\hline DESTINATION & P-1 & P-4 & P-5 & P-2 & P-3 & OUTPUT & OUTPUT & OUTPUT & OUTPUT & I OUTPUT & OUTPUT \\
\hline \multicolumn{12}{|c|}{ STREAM PROPERTIES } \\
\hline Temp $\left({ }^{\circ} \mathrm{C}\right)$ & 25.000 & 25.000 & 25.000 & 25.000 & 25.700 & 25.700 & 25.000 & 25.000 & 25.000 & 25.700 & 25.700 \\
\hline Pressure (bar) & 1.000 & 1.000 & 1.000 & 1.000 & 1.000 & 1.000 & 1.000 & 1.000 & 1.000 & 1.000 & 1.000 \\
\hline Density $(g / L)$ & 995.442 & 995.295 & 994.804 & 994.789 & 994.482 & 994.452 & 1.799 & 1.799 & 1.799 & 994.756 & 994.860 \\
\hline \multicolumn{12}{|c|}{ COMPONENT FLOWRATES (kg/h averaged) } \\
\hline Benzene & 25.000 & 0.000 & 0.000 & 0.000 & 0.000 & 0.000 & 0.000 & 0.000 & 0.000 & 0.000 & 0.000 \\
\hline Biomass & 15.660 & 85.864 & 282.889 & 254.532 & 72.723 & 0.727 & 0.000 & 0.000 & 0.000 & 181.809 & 71.996 \\
\hline $\mathrm{CO}_{2}$ & 0.000 & 0.000 & 0.000 & 0.000 & 0.000 & 0.000 & 60.194 & 173.229 & 1.640 & 0.000 & 0.000 \\
\hline Dead Biomass & 0.000 & 10.305 & 44.251 & 74.795 & 21.370 & 0.214 & 0.000 & 0.000 & 0.000 & 53.425 & 21.156 \\
\hline Glucose & 783.000 & 582.904 & 5.474 & 0.007 & 0.006 & 0.005 & 0.000 & 0.000 & 0.000 & 0.002 & 0.000 \\
\hline Water & 156600.000 & 156684.394 & 156857.623 & 156859.263 & 125649.885 & 116475.661 & 0.000 & 0.000 & 0.000 & 31209.378 & 9174.224 \\
\hline TOTAL (kg/h) & 157423.660 & 157363.467 & 157190.237 & 157188.597 & 125743.984 & 116476.607 & 60.194 & 173.229 & 1.640 & 31444.614 & 9267.376 \\
\hline TOTAL (L/h) & 158144.483 & 158107.362 & 158011.263 & 158011.998 & 126441.689 & 117126.424 & 33459.700 & 96291.829 & 911.844 & 31610.379 & 9315.256 \\
\hline
\end{tabular}

Table 8: Component Balance and Stream Report at 25\% Benzene

\begin{tabular}{|c|c|c|c|c|c|c|}
\hline Stream & Benzene & Biomass & $\mathbf{C o}_{\mathbf{2}}$ & Deadbiomass & Glucose & Water \\
\hline S-1 & 0.158 & 0.099 & 0.000 & 0.000 & 4.951 & 990.234 \\
\hline S-2 & 0.000 & 0.543 & 0.000 & 0.065 & 3.687 & 991.000 \\
\hline S-3 & 0.000 & 1.790 & 0.000 & 0.280 & 0.035 & 992.699 \\
\hline S-4 & 0.000 & 1.611 & 0.000 & 0.473 & 0.000 & 992.705 \\
\hline S-5 & 0.000 & 0.575 & 0.000 & 0.169 & 0.000 & 993.738 \\
\hline S-6 & 0.000 & 0.006 & 0.000 & 0.002 & 0.000 & 994.444 \\
\hline S-8 & 0.000 & 0.000 & 1.799 & 0.000 & 0.000 & 0.000 \\
\hline S-10 & 0.000 & 0.000 & 1.799 & 0.000 & 0.000 & 0.000 \\
\hline S-12 & 0.000 & 0.000 & 1.799 & 0.000 & 0.000 & 0.000 \\
\hline S-13 & 0.000 & 5.752 & 0.000 & 1.690 & 0.000 & 987.314 \\
\hline S-15 & 0.000 & 7.729 & 0.000 & 2.271 & 0.000 & 984.860 \\
\hline
\end{tabular}

Table 9: Mass Concentration for the Components (G/ L) at 25\% Benzene

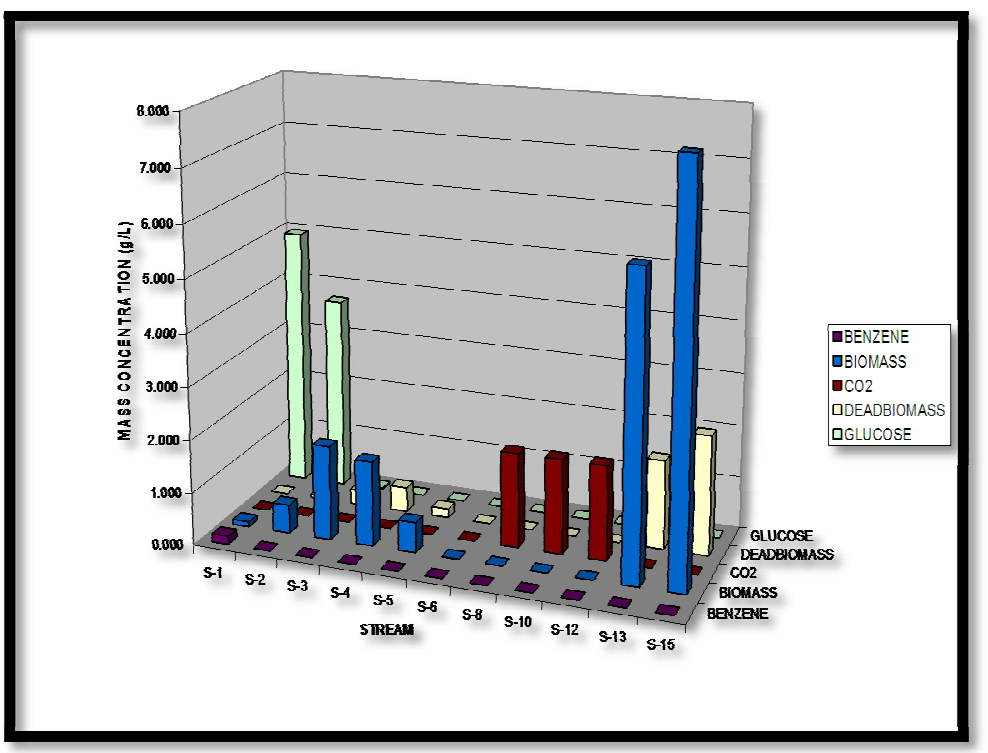

Figure 8: Mass Concentration of Components at 25\% Benzene

The figure above showed that at 25\% influents of benzene, stream S-1 contained benzene that was introduced into the first aeration tank at $0.158 \mathrm{~g} / \mathrm{l}$, which later reduced to $0.000 \mathrm{~g} / \mathrm{l}$ in the second aeration tank and to $0.000 \mathrm{~g} / \mathrm{l}$ in the third tank as revealed in equation 50. Biological oxidation of organic contaminants took place in these three tanks. $0.000 \mathrm{~g} / \mathrm{l}$ was released into the ultrafilter and $0.000 \mathrm{~g} / \mathrm{l}$ came out from the clarifier. Nothing was emitted from the first tank 
and nothing came out from the second tank as emission. Also, biomass of $0.099 \mathrm{~g} / \mathrm{l}$ entered into the first tank and was increased to $1.790 \mathrm{~g} / \mathrm{l}$ in the second tank because of biomass generation in equations 49 and 50 which later reduced to $1.611 \mathrm{~g} / \mathrm{l}$ because of biomass decay to deadbiomass and further reduction took place in ultrafilter to $0.575 \mathrm{~g} / \mathrm{l}$ where there was separation of suspended sludge and solutes of high molecular weight from solutes of low molecular weight through a semi permeable. Since biomass is not a gas, it came out as a sludge in both ultrafilter and clarifier that is, $5.752 \mathrm{~g} / \mathrm{l}$ in S-13 and $7.729 \mathrm{~g} / \mathrm{l}$ in S-15 respectively.

$\mathrm{CO}_{2}$ was not initially introduced into the biofilter, but later generated from glucose and benzene degradations in equations 49 and 50 respectively. Deadbiomass was not introduced into the system initially, but it was later generated from biomass decay in equation 51 . Glucose came in at $4.951 \mathrm{~g} / \mathrm{l}$ and later reduced to $0.000 \mathrm{~g} / \mathrm{l}$, no glucose came out as sludge. However, water of $990.200 \mathrm{~g} / \mathrm{L}$ concentration entered as input in S-1 as the major component and remained almost constant.

\begin{tabular}{|c|c|c|c|c|}
\hline Composition & $\begin{array}{c}\text { Influent Mass } \\
\text { Flow Rate } \\
\text { (kg/ hr) }\end{array}$ & $\begin{array}{c}\text { Influent } \\
\text { Percentage Mass } \\
\text { Composition (\%) }\end{array}$ & $\begin{array}{c}\text { Effluent Mass } \\
\text { Flow Rate } \\
\text { (kg/ hr) }\end{array}$ & $\begin{array}{c}\text { Effluent } \\
\text { Percentage Mass } \\
\text { Composition (\%) }\end{array}$ \\
\hline Water & 156600.000 & 99.429 & 118848.73510 & 99.9994 \\
\hline Glucose & 783.000 & 0.497 & - & - \\
\hline Biomass & 15.660 & 0.010 & 0.50515 & 0.0004 \\
\hline Benzene & 100.000 & 0.063 & - & - \\
\hline Dead Biomass & - & - & 0.20455 & 0.0002 \\
\hline
\end{tabular}

Table 10: Summary of Simulation Results

\section{Conclusions}

This work focused on modelling and simulation of biofilter system for abattoir wastewater treatment using bioreactors in series. The bioreactor performance was determined for benzene concentration of 100, 75, 50 and $25 \%$ in the abattoir wastewater. The following conclusions are arrived at;

- $\quad$ The resulting model reduced the level of benzene, biomass and glucose (contaminants) in the abattoir wastewater.

- The application of three bioreactors in series has also improved the performance of the biofilter.

- There were significant differences in the results of the mathematical modelling and process simulator using t-test at $\mathrm{p}<0.05$.

- The work has also provided information on the superiority of the Simulation package used in this work over model derived from first principles. The comparison of this work with the works of other researchers from the previous researches showed good agreement.

\section{Recommendations}

Many types of wastewater can be treated biologically with proper analysis and environmental control. Changes in the environment must allow the organisms to adapt or the effects may be highly detrimental. The following recommendations are therefore suggested:

- In the future, research must focus on the development of systems that can increase the rate of the treatment process to decrease retention times and subsequently reactor volumes.

- Experts in design, operation and biological processes will need to combine their efforts to enhance biofilter system performance, particularly for the treatment of recalcitrant compounds such as benzene.

- Process assumptions made in the mathematical modelling should be minimized in order to improve its accuracy.

- The composition of the biomass produced from the sludge suggests that it would be a useful fertiliser on grassland or for a number of arable crops and as cake for fish feed.

\section{References}

i. Adeyemo, O. K, Ayodeji, I. O and Aiki-Raji, C. O. (2002). The Water Quality and Sanitary Conditions in a major Abattoir (Bodija) in Ibadan, Nigeria. Afr. J. Biomed. Res.: Vol 5:51- 55.

ii. Meadows, R. (1995). Livestock Legacy. Environmental Health Perspectives 103 \{12\} 1096; 1100.

iii. Masse, D. I. and Masse, L. (2000). Characterization of Wastewater from Hog Slaughterhouses in Eastern Canada and Evaluation of their in-plant Wastewater Treatment Systems. Canadian Agricultural Engineering, 42 (3) 139 - 146.

iv. Quinn J.M. and McFarlane, P.N. (1989). Effects of Slaughterhouse and Dairy Factory Wastewaters on Epilithon: A Comparison in Laboratory Streams. Water Research 23:1267-1273.

v. Sangodoyin, A.Y. and Agbawhe, O.M. (1992). Environmental study on surface and groundwater pollutants from abattoir effluents. Bioresource Technology 41:193-200.

vi. Sayed, S.K.I. (1987). Anaerobic Treatment of Slaughterhouse Wastewater Using the UASB Process. PhD thesis. Wageningen, the Netherlands: Agricultural University of Wageningen. 
vii. Tritt, W.P. and Schuchardt, F., (1992). Materials Flow and Possibilities of Treating Liquid and Solid Wastes from Slaughterhouses in Germany. Bioresource Technology 41:235-245.

viii. Bull, M.A., Sterritt, R.M., and Lester, J.N., (1982). The Treatment of Wastewaters from the Meat Industry: A review. Environmental Technology Letters 3:117-126.

ix. Sayed, S. and de Zeeuw, W. (1988). The performance of a continuously operated flocculent sludge UASB reactor with slaughterhousewastewater. Biol. Wastes 24, 199-212.

x. Johns, M.R. (1995). Developments in Wastewater Treatment in the Meat Processing Industry: A review. Bioresource Technology 54:203-216.

xi. Hoang, T. L, Vigneswaran, S., Ngo, H. H., Kandasamy, J, Shim, W. G, Chaudhary, D. S, Gotety, P and Peiris, P (2008). Performance Evaluation and Mathematical Modelling of Granular Activated Carbon Biofiltration in Wastewater Treatment. Korean J. Chem. Eng., 25(2), 259-267

xii. Bai, Y., Zhang, J., Li, Y., Gao, Y,and Li,Y (2005). Biomass and Microbial Activity in a Biofilter during Backwashing. J Zhejiang Univ Sci B. 6(5): 427-432.

xiii. Rene, E. R, Kim, J. H.and Park, H. S. (2008). An Intelligent Neural Network Model for Evaluating Performance of Immobilized Cell Biofilter Treating Hydrogen Sulphide Vapors. Int. J. Environ. Sci. Tech., 5 (3), 287-296

xiv. Wik, T (2003). Trickling filters and biofilm reactor modelling. Reviews in Environmental Science and Bio/ Technology 2: 193-212.

xv. Skjelhaugen, O. J., Donantoni, L., (1998). Combined aerobic and electrolytic treatment of cattle slurry. J. Agric. Eng. Res. 70, 209-219.

xvi. USEPA, (2000). Generation, management and regulation of biosolids in the US under the EPA part 503 biosolids rule. Environmental Protection Agency, Washington, D.C.

xvii. Systems thinking, (2004). Modelling and simulation. www.systems-thinking.org

xviii. Devinny, J.S., Deshusses, M.A. and Webster, T.S (1999). Biofiltration for air pollution control, in: Modelling Biofiltration, Lewis Publishers, pp. 111-112.

xix. Dictionary 3.0 (2010). Ultrafiltration. www.dictionary3.0.com

xx. Sensagent, (2011). Sedimentation. www.dictionary.sensagent.com

xxi. Polprasert, C., Kemmadamorong, P. and Tran, F.T (1992). Anaerobic baffle reactor (ABR) process of treating a slaughter house wastewater. Envir. Technology. 13: 857 - 865

xxii. Grady, C. P. L., Jr. and Lim, H. C. (1980). Biological Wastewater Treatment: Theory and Applications. Dekker, New York, N.Y. 